\title{
HOW ICT CAN ENHANCE THE ATTRACTIVENESS OF MATHEMATICS AND PHYSICS IN PRIMARY SCHOOL
}

\author{
Juraj Slabeycius, Daniel Polčin \\ Catholic University in Ruzomberok, Ružomberok, Slovakia \\ E-mail: juraj.slabeycius@ku.sk, daniel.polcin@ku.sk
}

\begin{abstract}
The study deals with the causes and consequences of disinterest of pupils in mathematics and physics and looking for a way how to increase the attractiveness of these subjects in primary and secondary schools. One possibility is the use of information and communication technologies in the teaching process. The study refers on EDULAB project, created as an initiative of $N G O$ and private sector. Its aim is to create a wide program of electronic education and support material for schools based on ICT. The EDULAB education center gives primary and secondary schools in Slovakia the opportunity to gain practical skills in the application of ICT in education. Via the portal www.naucteviac.sk EDULAB provides schools more than 30000 multimedia resources for five science subjects. These are multimedia materials of company Young Digital Planet, known as "universal curriculum" tailored to national language. Nevertheless, the latest computer technology, interactive whiteboards, other computer peripherals and multimedia elearning programs don't give school the guarantee for an increase of the of pupils' knowledge, as long as the digital learning materials contain a number of errors and unacceptable simplification.
\end{abstract}

Key words: digital education, ICT, EDULAB, physics teaching, misconception in physics.

\section{Introduction}

In Slovakia, for a long time remains disinterest of young people to study natural science and technical disciplines. Students of technically oriented faculties have insufficient knowledge of mathematics and physics, you find them very difficult and therefore they have problem with understanding of technical subjects. This problem has a significant economic aspect - industries have a shortage of qualified staff. Despite the high unemployment rate in Slovakia is a problem attracting young, talented professionals, which are able to develop new progressive products. Slovakia is slowly but surely becoming "assembly workshop of Europe." The proportion of highly sophisticated technologies on manufacturing in Slovakia is one of the lowest in the EU countries.

The cause of poor knowledge of pupils in mathematics and physics is to be sought at the primary schools. These subjects are not attractive; many pupils consider them very difficult, tedious and incomprehensible. On one hand, Slovak education system can to capture and nurture talented individuals, as evidenced by successes in international competitions and subjects olympiads, on the other hand, knowledge of the average pupil are at a very low level. Worrying is the fact that despite the improving equipment of schools, the average level of knowledge of pupils doesn't increase. Therefore it is necessary to improve the motivation of pupils and teachers to create suitable social and material conditions for more effective teaching and attractiveness of teaching mathematics and science subjects. 
PROBLEMS

OF EDUCATION

IN THE $21^{\text {st }}$ CENTURY

Volume 50, 2012

One of ways to do this is to use modern progressive methods of teaching using ICT. The Slovak government has adopted in 2007 the Concept of using information and communication tools in education (Koncepcia informatizácie školstva, 2007) which states: "The fundamental prerequisite for the successful participation of the Slovak Republic into the global information space and the global economy is the high educational level of its citizens. Education and training are therefore crucial for informatization of the society. Therefore it is necessary to achieve in the education sector following global objectives:

- Education in informatics, where informatics is the subject and tool and education is oriented to prepare professionals in computer science and informatics.

- Education in other areas using informatics methods and tools that creates informatization of education. Information technology is a tool which enables the introduction of new, effective forms of education, supporting interculturalization of education.

- Eliminate digital splitting of society, to create the conditions for the acquisition of basic digital literacy during compulsory education for every pupil.

- Build and develop information systems at all levels of management to carry out management activities in the education sector and its operations."

The European Commission also pays great attention to the use of ICT in education. The building of modern ICT infrastructure for all types of schools is one of priorities EU. Internet access in schools is also very important condition. In 2006, $76 \%$ of children in EU had access to computers at home. This ratio grew in 2009 to $86 \%$. Especially, in Slovakia $69 \%$ of children disposed of a computer at home in 2006, while in 2009 the ratio was $86 \%$ (Key data on Learning, 2011). However, the successful use of computers in educational contexts is dependent not only on their availability but also on users' familiarity with them.

The computerization and digitization of educational structures includes as one of the activities EU operational program „Education“ and the operational program „Research and Development". Over the past five years has significantly improved equipment of all types of schools by interactive Whiteboards, computers and peripherals. The vast majority of schools gained access to high-speed internet, mainly through fiber optic cables. All high schools and some middle schools are equipped with videoconferencing rooms, enabling remote contact of conference participants.

On the other hand, the use of expensive ICT equipment in schools, especially primary schools, is not at a sufficient level. According to survey in fourth grade of primary schools in 2007 year, a relatively large share of students had teachers who never required them use a computer even where they were available in the classroom. However, in Slovakia is situation not so bad: about $70 \%$ of pupils are forced by their teacher to use a computer for practicing skills and procedures and more than $90 \%$ for looking up ideas and information during science teaching (Key data on Learning, 2011).

Recently, there were also some initiatives of non-governmental organizations and the private sector towards the creation of a large digital educational content and support materials for school based on ICT. One of such initiatives is the project EDULAB (The center of modern, 2010).

\section{The EDULAB Project}

The center of modern educational technology EDULAB was founded in 2010 as a commercial activity AGEMSOFT Companies, Inc., which provides in Slovakia products of the Polish company Young Digital Planet (Young Digital Planet, 2000). In 2012 EDULAB was transformed into a non-profit organization with partners "Association of directors of state secondary grammar school in Slovakia", "The association of self-governing schools in 
Slovakia", commercial company Atos IT Solutions and Services, Publishing House Dr. Joseph

Raabe Slovakia and Intel Corporation.

EDULAB is a unique center of modern technology in the city of Bratislava, capital of Slovakia, designed for effective application of ICT and for using of digital educational content in the learning process. It is a prototype of future modern multimedia classroom, which represents a comprehensive hardware and software solutions in educational practice with a primary focus on all types of schools and educational organizations. The main aim of the center EDULAB is to increase the popularity of using of modern educational technologies in schools and show the benefits and importance of genuine modernization of education. EDULAB gives teachers the opportunity to gain practical skills by training and trying the work with the latest technologies with pupils (The center of modern, 2010).

In March 2012, the center EDULAB announced program of support of schools digitization. In the frame of this program were established 20 innovative information centers in all regions of Slovakia, which helping schools to familiarize themselves with digital technologies. Any school in Slovakia can join the program. There are approximately 2,200 primary schools, 250 secondary grammar schools and 500 secondary vocational schools in Slovakia. The program offers a variety of benefits for schools and teachers who register and agree to the conditions for users. The first thousand schools registered in the program will receive free access to the digital educational content for one year. This content is placed on the portal www.naucteviac. sk and contains more than thirty thousand digital resources for five subjects: mathematics, physics, chemistry, biology and science. In addition, the website contains articles and materials for English language and computer science. These materials are continuously updated and supplemented.

Registered teachers can quickly and easily search necessary material in portal by using keywords and other tools. On most issues, there is the several videos, animations, pictures and graphs, so the teacher can create preparation for his lesson. He can used not only digital materials from portal, but also upload your own material into the lesson. The teacher can create homework for pupils, place it to portal and supervise them.

In EDULAB various activities and events are implemented, such as seminars, trainings, presentations, open classes and scientific discussions. Pupils have the opportunity, along with their teachers visit the EDULAB center in Bratislava and try yourself an sample lesson in the multimedia classroom. Moreover EDULAB will support in each school year, at least 10 projects for the creation and use of digital educational content by EUR 1000 per project.

\section{Universal Curriculum}

Universal Curriculum is a set of multimedia training materials which provide the Young Digital Planet company (Universal Curriculum, 2004). As the company presents on its website, the content of the curriculum is divided into more than 1100 topics, which are available in two versions - for teachers and pupils, taking into account their different needs. The curriculum includes more than thirty thousand high quality interactive resources in mathematics, science, chemistry, physics and biology for pupils between 10 and 19 years of age. Material is wellordered; it can be easily adapted to national needs in terms of curriculum, language and form. The user-friendly environment for teachers and students and its high quality meant that the curriculum gained recognition in more than 25 countries worldwide. In Slovakia, curriculum is offered by AGEMSOFT company under the name "Planet of Knowledge" (Planéta vedomostí, 2010).

Due to the large number of shortcomings and mistakes this product was strongly criticized by the community Slovak Physicists (Mojžišs, 2011). The main objections were: Lack of systematic explanation, conservative approach of teaching, lack of support of creative 
PROBLEMS

OF EDUCATION

IN THE $21^{\text {st }}$ CENTURY

Volume 50, 2012

104

thinking, ladge number of errors. The curriculum contains too many facts with too little context. The product is too expensive. Nor the authors of lessons neither the reviewers are known.

For those interested in curriculum the company offers on its website sample lessons for each level (Sample e-lessons, 2004). For the lower secondary level the theme of the sample lesson in physics is "Addition of forces" (Sample lesson 1, 2004). The two cases are analyzed in the lesson - "A drop of a parcel" and "A boat on the river" (Figure 1).

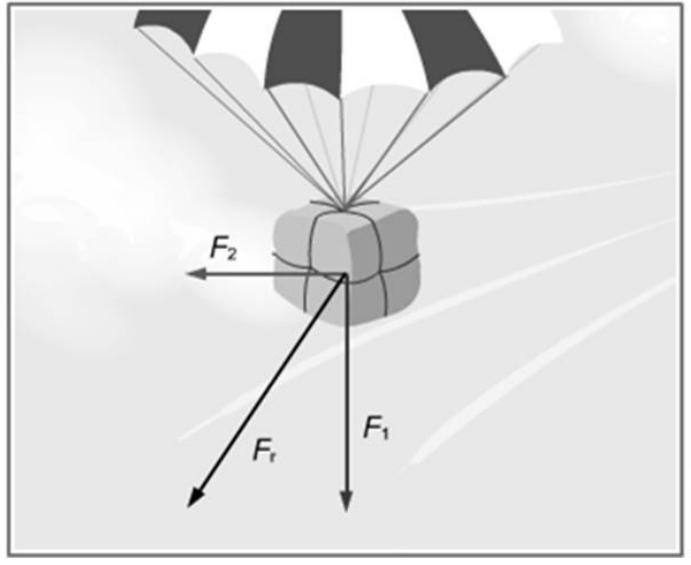

a)

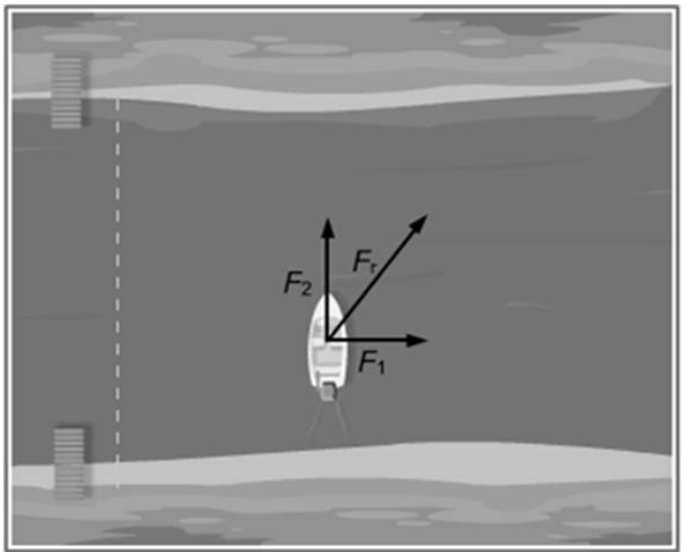

b)

Figure1: a) A drop of a parcel; b) A boat on the river.

According to the animation and the accompanying commentary the parcel is affected by two forces - force of gravity and wind force. The sum of these two forces creates resulting force, which determines the direction of the parcel's flight. This comment is fundamentally incorrect. The velocity of parcel on parachute very quickly stabilizes at a value for which the gravitational force is balanced by a drag force caused by resistance of air, and further movement has been steady straightforward (assuming a constant velocity of crosswinds).

As known from Newton's laws of motion, the sum of forces acting on body moving uniformly straightforward is zero. Aristotle's notion that force is the cause of the motion and without the force movement ceases, Isaac Newton refuted more than three hundred years ago. This example might serve to illustrate the addition of velocities, but not the addition of forces. Moreover, cross-wind does not act at all on the parcel in steady straightforward motion, because the parcel will be falling straight down relative to air - the horizontal component of its velocity will be equal to the cross-wind speed.

Second case described a boat floating across the river. According to the comment, the engine acts on the boat with the force $F_{2}$ and water with the force $F_{1}$ in the flow direction. Resultant force determines the direction of the boat movement. As in the first case, the comment is completely wrong. Analysis is similar to first one. While the boat is motionless, the buoyancy force is balanced by gravity force, so in vertical direction is sum of forces equal to zero. When the engine is turn on, boat accelerates but at the same time the resistance power of the water increasing. This force depends on the mutual speed of boat and water, and very quickly an equilibrium state is reached, in which the boat is moving at a constant speed relative to water. The total force acting on the boat will be zero.

The term „force“ is closely related with Newton's laws of motion. This topic is also included in the curriculum, but it is not freely available for non registered users. The last two examples provide a very good test, as far the teachers understand of Newton's laws of motion. 
According to YDP website, its universal curriculum ,already having gained approval and recognition in over 25 countries worldwide". It means that tens of thousands of physics teachers in 25 countries are satisfied and agrees with such interpretation. The conclusion is clear, but very worrying - the vast majority of teachers understand Newton's laws merely formal.

More optimistic explanation is, that teachers have doubts about the correctness of above mentioned lesson, but either they consider as acceptable simplification that is appropriate to the age of pupils, or bow to authority of the textbook. But universal curriculum is not a textbook that has writers who are liable for the accuracy, reviewers, who do comprehensively assess the professional, didactic and artistic point of view - it's just a set of multimedia materials, which introduced the company YDP. Neither the authors nor the reviewers can be found on any website of YDP.

Third, a more realistic explanation is that teachers, who understand the physical absurdity of the arguments in the curriculum, simply discard this material and make the interpretation of his own. Unfortunately, such materials are also in a version for pupils, who are unable to detect these mistakes. However, the universal curriculum contains a lot of correct information and useful multimedia materials for students and teachers, but it must be subjected to critical analysis.

The misunderstanding of Newton's laws of motions was studied by many authors (Dykstra, 1992; Tao, 1999). Well known is the Force concept inventory test (Halloun, 1985; Hestenes, 1992), which allows identifying student's concepts of force and motion. Aristotle's concepts in mechanics are quite intuitive and remain as working concepts for many people regardless of whether they are teachers, students or ordinary people.

Balažovič and Tomášik (Balažovič, 2012) tested more than 800 students from 11 grammar school in Slovakia. They used a simple test consist of four question. As an example, one of them: "The ball moves uniformly from right to left influenced by the two forces. Add one or more additional forces, if it is for such type of motion necessary." Students should draw force vector into the picture (Figure 2).

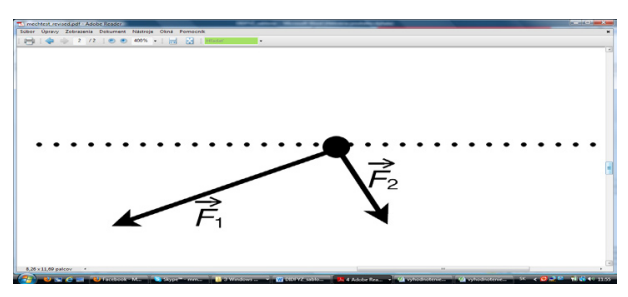

Figure 2: Uniformly moving body - add a force.

Only $17 \%$ of answers were correct. Most students drew the downward force (gravitational force ?), other incorrect answers were related to the friction force. About $22 \%$ of answers corresponded Aristotles' concept of movement. Overall average success rate in complete test was about 25 percents. The results weakly depend of the year of study - from $22 \%$ in the $1^{\text {st }}$ yar to $28 \%$ in the last year of grammar school study.

Similar results were obtained in many other studies (Jimoyiannis, 2003; Chang, 2007; Bayraktar, 2009). It indicates that misconception in physics, especially in mechanics are widespread among the students and unfortunately among the teachers, too. The part of responsibility for this situation lies on educational system, textbooks and multimedia materials and also on not enough good prepared teachers. 


\section{PROBLEMS \\ OF EDUCATION \\ IN THE $21^{\text {st }}$ CENTURY \\ Volume 50, 2012 \\ 106 Conclusions}

Lack of interest of pupils in physics and mathematics is a serious problem for society. A very important task is therefore finding ways to make these subjects more interesting and understandable. The use of ICT can play crucial role in it. Activities of educational center EDULAB and its program of support digitization of schools represent the system way of using of digital technologies in the educational process. Establishment of educational portal www. naucteviac.sk allows a large number of teachers and pupils to use modern digital technology in the educational process and thus more effective and attractive teaching. However, digital resources Universal curriculum on which the portal www.naucteviac.sk is based must be subjected to critical analysis and must be removed all false, misleading and inaccurate information and interpretation.

\section{Acknowledgements}

The authors would like to thank the Slovak Cultural and Educational Grant Agency for supporting of actual work under grants KEGA No. 032KU-4/2012.

\section{References}

Koncepcia informatizácie školstva SR. (2007). Retrieved Sept.28, 2012 from http://www.min edu.sk/ index.php?lang=sk\&rootId $=1292$

The center of modern educational technologies EDULAB (2010). Retrieved Sept.28, 2012 from http:// www.edulab.sk/ed-hlavna-stranka.html

Universal Curriculum (2004). Retrieved Sept.28, 2012 from http://www.ydp.eu/solutions/ upper-primaryand-secondary-maths-science/universal-curriculum.

Sample e-lessons (2004). Retrieved Sept.28, 2012 from http://www.universalcurriculum.com/ elearning/ index.php?category $=30$

Sample lesson 1. (2004). Retrieved Sept.28, 2012 from http://www.universalcurriculum.com /Sample lessons1/localplayer/page.html?sco=../Physics_LS/uc_p4t_1002.flo

Key data on Learning and Innovation through ICT at schools in Europe. (2007) Retrieved Sept.28, 2012 from http://eacea.ec.europa.eu/education/eurydice/documents/ key_data_series /129EN.pdf

Planéta vedomostí (2010). Retrieved Sept.28, 2012 from http://www.planetavedomosti.sk

Young Digital Planet, SA. (2000) Retrieved Sept.28, 2012 from http://www.ydp.eu

Dykstra, D. I. Et al. (1992). Studying conceptual change in learning physics. Science Education, 76, 615-652.

Hestenes, D. Et al. (1992). Force Concept Inventory. The Physics Teacher, 30, 141-158.

Halloun, I., \& Hestenes, D. (1985). Common sense concepts about motion. American Journal of Physics, $53,1056-1065$.

Mojžiš, M. (2011). Planéta čudných vedomostí (Planet of strange knowledge). Týždeň, 23, 24-27.

Balažovič, M., \& Tomášik, B. (2012). Aristoteles v nás (Aristotle inside us). DIDFYZ 2012, 17.-20. Oct. 2012, High Tatras, Slovakia. Conference proceedings (to be published)

Tao, P. K., \& Gunstone, R. F. (1999). The process of conceptual change in force and motion during computer-supported physics instruction. Journal of Research in Science Teaching, 36, 859-882.

Jimoyiannis, A., \& Komis, V. (2003). Investigating Greek students'ideas about forces and motion. Research in Science Education, 33, 375-392.

Bayraktar, S. (2009). Misconceptions of Turkish pre-service teachers about force and motion. International Journal of Science and Mathematics Education, 7, 273-291.

Chang, H. P. et al. (2007). Investigating primary and secondary students learning of physics concepts in Taiwan. International Journal of Science Education, 29, 465-482. 
Juraj SLABEYCIUS, Daniel POLČIN. How ICT Can Enhance the Attractiveness of Mathematics and Physics in Primary School

\begin{tabular}{l|l} 
Advised by Vincentas Lamanauskas, University of Siauliai, Lithuania & $\begin{array}{l}\text { PROBLEMS } \\
\text { OF EDUCATION } \\
\text { IN THE 21 } 1^{\text {st }} \text { CENTURY } \\
\text { Volume 50, 2012 }\end{array}$ \\
\end{tabular}

Received: October 20, 2012

Accepted: December 05, 2012

\begin{tabular}{|ll} 
Juraj Slabeycius & PhD., Professor, Catholic University in Ruzomberok, Faculty of Education \\
& Hrabovská cesta 1, 034 01 Ružomberok, Slovakia. \\
& E-mail: juraj.slabeycius@ku.sk \\
\hline \multirow{2}{*}{ Daniel Polčin } & PhD., Associate Professor, Catholic University in Ruzomberok, Faculty of Education \\
& $\begin{array}{l}\text { Hrabovská cesta 1, 034 01 Ružomberok, Slovakia. } \\
\text { E-mail: daniel.polcin@ku.sk }\end{array}$
\end{tabular}

